\title{
FACTORS INFLUENCE CUSTOMERS PURCHASE INTENTION TOWARDS HYPERMARKETS AT KOTA BHARU, KELANTAN
}

\author{
Lu Man Hong1,", Muhammad Azim Abu Hassan Sha'ari², Darshini Annamalai ${ }^{3}$, Muhammad Syahril \\ Amin Bin Norazmi ${ }^{4}$, Nurul Asikin Binti Hizani ${ }^{5}$, Tan King Kiat ${ }^{6}$ \\ 1,3,4,5,6Faculty of Business and Entrepreneurship, Universiti Malaysia Kelantan, Malaysia \\ ${ }^{2}$ Department of Muamalat, Sultan Ismail Petra International Islamic College, Kota Bharu, Kelantan \\ Email: ${ }^{1}$ vicklumanhong@gmail.com; ${ }^{2}$ azimabuhassan@gmail.com; ${ }^{3}$ darshini.a16a0120@ siswa.umk.edu.my; \\ 4syahril.a16a0437@siswa.umk.edu.my; ${ }^{5}$ asikin.a16a1340@ @iswa.umk.edu.my; ${ }^{6}$ kingkiat.a16a1364@siswa.umk.edu.my \\ *Corresponding author
}

\begin{abstract}
The study's goal was to look into the relationship between price, product quality, and interior atmosphere and customers' purchasing intentions in the Kota Bharu, Kelantan area. Kota Bharu Mall, Aeon, Billion, Tesco, Mydin, Giant, and Pantai Timur Hypermarket were among the hypermarkets studied. Furthermore, this study was carried out to establish what the most influential variables were that which affect consumers' buying intentions and, as a result, how they chose their favourite hypermarket. The independent variables in this study were price, product quality, and interior atmospheric, while the dependent variable was purchasing intention. In this research, a questionnaire survey was used to collect data from customers at seven hypermarkets in Kota Bharu. A total of 417 accurate and usable questionnaires were collected, with responses reported on a fourpoint Likert-type scale, with one indicating strong disagreement and four indicating strong agreement. All of the independent variables were found to be strongly related to the dependent variables in the sample. Product quality had the highest positive correlation with purchasing intention following by Interior atmospheric and price came in second and third. This demonstrated that even minor changes in all of the independent variables had an impact on purchasing intent. However, the multiple regression analysis result indicated product quality as most infleunctial factor in this study although three independent variables found significant.
\end{abstract}

Keywords: Hypermarket, interior atmospheric, purchase intention, price, product quality.

\section{Introduction}

In today's world, the retail industry is a rapidly growing economic field that also serves as a major market draw (Krisnakumar et al., 2018). Specialty stores, department stores, supermarkets, grocery stores, discount stores, off-price stores, superstores, hypermarkets, and catalogue showrooms all exist in Malaysia. Hypermarkets, which are a mix of grocery stores, department stores, and discount stores, are the most modern of all the retail stores (Krisnakumar et al., 2018). According to Hassan, Rahman, and Sade (2019), hypermarket are modern supermarkets that cater to a wide variety of basic household needs. The retail landscape has been changed from a conventional to a more contemporary concept as a result of the growth of the retail momentum. As a result of this transformation, the majority of customers choose to shop at hypermarkets rather than conventional grocery stores (Jaliawala \& Rahman, 2014). Malaysia's retail industry has experienced rapid growth in recent decades, especially in hypermarkets, which has altered the country's market structure and shopping landscape (Cheng, 2015). Hypermarkets began to become more effective and profitable in the year 1993. In Malaysia, there are two types of hypermarkets. The first is a hypermarket with an international base, while the second is a hypermarket with a local base. According to Alhabshi (2014), local-based hypermarkets contribute to economic growth while foreign-based hypermarkets sustain the nation's socio-economic balance. According to the International Markets Bureau (2012), Malaysia is the country with the highest sales proportion in the contemporary retail format, at 88 percent, which includes hypermarkets. This demonstrates how much Malaysians enjoy hypermarkets. Malaysians prefer shopping in hypermarkets over other retail outlets because hypermarkets serve as a one-stop shop (Shamsudin \& Selamat, 2005).

The survey was conducted in Kelantan's Kota Bharu. Mydin, Billion, Pantai Timur Hypermarket, Tesco, Aeon, KB Mall, and Giant are among the hypermarkets in Kota Bharu. In Kota Bharu, Kelantan, there are nearly seven hypermarkets. According to the Department of Statistics Malaysia's Official Portal, Kelantan has a population of 1.86 million people, while Kota Bharu has a population of 577,301 people in 2019. One of the reasons for marketers to locate their hypermarkets in Kota Bharu Kelantan may be the population. Customers who shop at these hypermarkets do not vary significantly in terms of demographics, age, or social status. All of these hypermarkets are relatively close together in terms of distance. Customers did have the option of remaining loyal to 
specific hypermarkets. Consumers today are very demanding, and their shopping habits are changing over time (Ahmed, Zamir, Yazdani, \& Mehmood, 2016) because of the wide range and depth of product offerings, consumers prefer hypermarkets to buy groceries and household items (Lee, Looi, \& Woo, 2018). However, Customers are also having trouble choosing between a variety of locations, including grocery stores, supermarkets, discount stores, big stores, and hypermarkets (Rana, Osman, \& Othman, 2015). This compelled the researchers to investigate the factors that influence customers' decisions to shop at a specific hypermarket. As a result, the researchers were intrigued by these phenomena and decided to conduct research into the factors that influence a customer's decision to buy goods from a specific hypermarket. Thus, price, product quality, and interior atmosphere will all be included in this investigation to identify the most important factor affecting consumer buying intentions against hypermarkets.

\section{Purchase Intention}

According to Lim, Osman, Salahuddin, Romle, and Abdullah (2016), intention is a measure of how willingly people approach a specific type of behavior and how many times they attempt to conduct that particular behavior. Customers' willingness to buy a product or service is referred to as their intention to purchase. The intention to buy can also be described as the likelihood that a customer will buy a product after evaluating it. Many factors affected the consumer's intention when selecting a product, according to Younus, Rasheed, and Zia (2015), and with strong external influences, the final decision is dependent on the consumer's intention. Purchase intention is a form of decision making that investigates a consumer's motivations for buying a specific brand (Walintukan, Tumbuan, \& Tulung, 2018). Purchase purpose, according to Mirabi, Akbariyeh, and Tahmasebifard (2015), is an effective tool for predicting the purchase process and it defined as "the probability of customers attempting to buy a product is referred to as purchase intention". According to Hosein (2012), consumers' purchasing intent can be calculated on a regular basis and used by marketers as an input for predicting sales and market share.

\section{Price}

Price refers to what is given up or discarded in exchange for a good or service (Wang \& Chen, 2016). The price of a commodity is regarded as the most important factor in determining whether or not to buy it. According to Lien, Wen Huang, and Wu (2015), prices provide customers with knowledge about product quality. Customers' expectations of a hypermarket's price reasonableness in contrast to its competitors' prices is also important in forming favorable intentions and loyalty toward a hypermarket, according to empirical evidence (Han \& Hyun, 2015). It's often regarded as one of the most important determinants of consumer purchasing intent (Gilmore, 1974). Price is one of the most important factors in influencing a customer's decision to buy, according to Herrmann, Xia, Monroe, and Huber (2007). Price is an important factor in consumer transactions, and it has a significant impact on customer purchasing decisions (Kaura, Durga Prasad, \& Sharma, 2015). From the consumer's perspective, the price reflects the money spent on the same goods or services (Lien et al., 2015). Aside from that, most customers believe that price as a quality indicator represents the old adage that "you get what you pay for" (Lien et al., 2015). As a result, the following hypothesis about the relationship between price and purchasing motive is proposed:

$H_{I}=$ There is a significant positive impact of price on customers purchase intention towards hypermarket at Kota Bharu Kelantan.

\section{Porduct Quality}

Razak, Nirwanto, and Triatmanto (2016) assumed that product quality is "the attribute of a product or service that bears on its ability to fulfil specified or implied consumer needs". According to Asshidin, Abidin, and Borhan (2016), the framework of quality that customers get has been generally acknowledged as the key driving force of the intention to buy in the field of marketing. Consumers would be more likely to buy a product if it is of higher quality. According to Mirabi et al. (2015), a better-quality product was greeted with a higher purchase intention. Consumers' perceptions of product quality are influenced by a variety of factors, including the time of purchase and the place where the product is purchased or enjoyed (Asshidin et al., 2016). According to Pandey (2015), it is difficult to find a company today that is unaware of quality and the consumer's increased focus on quality and value. Quality standards apply to a wide range of products, including automobiles, supercomputers, and even sweets.

$\mathrm{H}_{2}=$ There is a significant positive impact of product quality on customers purchase intention towards hypermarket at Kota Bharu Kelantan.

\section{Interior Atmosphere}

According to Kotler (1973), the term refers to a form of information that gives shoppers a specific emotional impact in order to increase the probability of 
purchasing. Atmospheres can be captured using the five essential human senses of sight, sound, smell, touch, and taste. As atmospheric or service-scape measurements, Bitner (1992) identified ambient conditions, spatial structure and functionality, as well as signs, symbols, and artefacts. Temperature, illumination, sound, music, and scent can all be used to discuss the essence of the universe. Following that, Derbaix (1987) described the atmosphere as "an emotionally oriented arrangement of the retail space to produce feelings of well-being, welcome, happiness, discount, and so on". "The attempt to build buying environments for the consumer to create unique emotional effects that increase the probability of purchasing" as the definition of atmospherics. Current studies (Nguyen, Jamal, O'Brien, \& Nawaz, 2017) agree that store atmospherics is used as a marketing tool to enable retail managers to prepare and track physical environmental factors that help to influence customer behavior and build positive shopping experiences. According to Hussain and Ali (2015), atmospheric variables such as smell, cleanliness, show, and lighting have a positive effect on consumers' purchasing intentions, while temperature has almost no impact.

$\mathrm{H}_{3}=$ There is a significant positive impact of interior atmospheric on customers purchase intention towards hypermarket at Kota Bharu Kelantan.

\section{Research Framework}

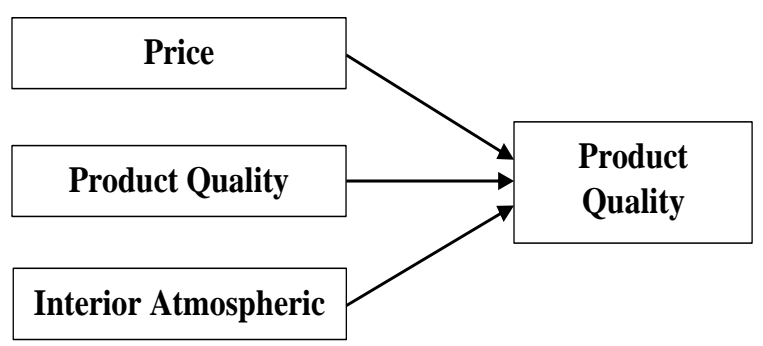

Independent Variables

Dependent Variable

Figure 1. Research framework

The relationship between the dimensions is clearly demonstrated and summarised by establishing this conceptual framework. Three independent variables (price, product quality, and interior atmospheric) are shown on the left side of the framework. These variables play a role in the positive effect on customers' buying intentions (dependent variable) against hypermarkets in Kota Bharu.

\section{Research Method}

The numeric measurement, also known as quantitative analysis, was used in this study. Customers who visited the hypermarkets region of Kota Bharu to provide feedback on the question posed to them were the respondents in this study. The sample size for this analysis was calculated by Krejcie and Morgan (1970), who recommended a sample size of 384 people. Nonetheless, 420 responses were collected in order to optimise the study's results. This study was conducted using a quantitative approach in which a survey was conducted by distributing a collection of questionnaires to a total of 420 respondents who are customers who frequent the hypermarkets region of Kota Bharu in order to obtain their feedback on the question posed to them. Only 417 responses were used in this study after the researchers reported 420 responses for data collection by distributing questionnaires Since the answer pattern was a straight-line response, three responses were filtered out. To prevent respondents from misinterpreting the meaning of items, the questionnaire was written in two languages (Malay and English). All of the items were created in a concise and understandable manner in order to elicit genuine feedback from the respondents. In addition, the questionnaire used a 4-point Likert scale ranging from 1 (strongly disagree) to 4 (strongly agree).

The questionnaire was divided into four sections: (a) demographic profile, (b) factors influencing customers' purchase intentions, (c) factors influencing target respondents' purchase intentions towards hypermarkets in Kota Bharu Kelantan activities, and (d) target respondents' perceptions of purchasing intentions in relation to factors. All of the data was analysed using the Statistical Programmers for Social Science (SPSS) version 22.0 software. A pilot study was the first evaluation that the researcher conducted. As a result, 30 responses were collected from the respondents in order to conduct the pilot study. According to Hair, Sarstedt, Ringle, and Mena (2012), the Cronbach's Alpha value, which must be greater than 0.70, determines the outcome of a reliability examination.

The second test performed was a frequency analysis to summarise the information gathered from the questionnaires. Simply placed, this study evaluated and summarised the demographic profile of 417 respondents into a table with frequency and percentages. According to Hair et al. (2012), descriptive analysis is the use of statistics to describe variables or generalize knowledge from a sample. Finally, the Pearson Correlation Coefficient Analysis was used to look at the relationships between the variables to determine how strong they were. The relationships between purchasing intention and three independent variables were discovered using this test (price, product quality and interior atmospheric). 


\section{Result and Discussion}

\section{Realibility Analysis}

According to Johnson and Christensen (2017) and Issaac and Michael (1995), a pilot study can be carried out by 10 to 30 participants, with 30 being the preferred value.

Table 1

Reliability Statistic

\begin{tabular}{ccc}
\hline Constructs & Cronbach's Alpha & $\boldsymbol{N}$ of Items \\
\hline Price & 0.78 & 5 \\
Product Quality & 0.80 & 5 \\
Interior Atmospheric & 0.78 & 5 \\
Purchase Intention & 0.86 & 5 \\
\hline
\end{tabular}

According to Table 1, a pilot study of 30 people will be performed. Cronbach's Alpha values for all constructs in this analysis range from 0.78 to 0.86 . In conclusion, the target respondents understand all of the items in this study since the Cronbach Alpha value for each construct must be greater than 0.70 . indicating that the target respondents understand the items in each component (Hair et al., 2012).

\section{Frequency Analysis}

Table 2

Summary of Demographic Profile

\begin{tabular}{llrr}
\hline \multicolumn{1}{c}{ Demographic Profile } & $\begin{array}{c}\text { Number of } \\
\text { respondents }\end{array}$ & Percentage \\
\hline Gender & Male & 169 & $40.50 \%$ \\
Age & Female & 248 & $59.90 \%$ \\
& Below 20 & 75 & $18.00 \%$ \\
& $21-30$ & 148 & $35.50 \%$ \\
& $31-40$ & 86 & $20.60 \%$ \\
Marital status & $41-50$ & 55 & $13.20 \%$ \\
& 50 and above & 53 & $12.70 \%$ \\
& Single & 216 & $51.80 \%$ \\
Race & Married & 180 & $43.20 \%$ \\
& Others & 21 & $5.00 \%$ \\
& Malay & 259 & $62.10 \%$ \\
& Chinese & 76 & $18.20 \%$ \\
Employment & Indian & 60 & $14.50 \%$ \\
status & Others & 22 & $5.30 \%$ \\
& Private sector & 81 & $19.40 \%$ \\
& Government sector & 92 & $22.10 \%$ \\
& Self-employment & 60 & $14.40 \%$ \\
& Students & 140 & $33.60 \%$ \\
& Retired & 29 & $7.00 \%$ \\
Monthly income & Others & 15 & $3.60 \%$ \\
& Below RM1000 & 158 & $37.90 \%$ \\
& RM1001-RM2000 & 39 & $9.40 \%$ \\
& RM2001-RM3000 & 111 & $26.60 \%$ \\
& RM3001-RM4000 & 60 & $14.40 \%$ \\
& RM4001-RM5000 & 26 & $6.20 \%$ \\
& Above RM5000 & 23 & $5.50 \%$ \\
& Primary school & 21 & $5.00 \%$ \\
& Secondary school & 162 & $38.80 \%$ \\
& Bachelor degree & 161 & $38.60 \%$ \\
& Master's degree & 39 & $9.40 \%$ \\
& Doctoral degree & 11 & $2.60 \%$ \\
& Others & 23 & $5.50 \%$ \\
\hline \multirow{5}{*}{ Education level } & & \\
& & &
\end{tabular}

In this study, female respondents outnumber male respondents, as seen in Table 2. The bulk of the respondents were between the ages of 21 and 30, followed by those between the ages of 31 and 40, and so on. In this analysis, 216 of the 417 participants were single. In addition, 259 Malay people responded, followed by Chinese people. Aside from that, 140 respondents were teachers, and 158 respondents had a monthly income of less than RM1000. Finally, the majority of respondents had completed high school, followed by a bachelor's degree. In summary, the majority of the respondents in this study were females between the ages of 21 and 30, single, Malay, and had a monthly income of less than RM1000.

Table 3

Respondent Feedback on the Hypermarket

\begin{tabular}{|c|c|c|c|}
\hline \multicolumn{2}{|c|}{ Respondent Feedback on The Hypermarket } & \multirow{2}{*}{$\frac{N}{32}$} & \multirow{2}{*}{$\begin{array}{r}\% \\
7.70 \%\end{array}$} \\
\hline How long have you & Less than 1 year & & \\
\hline \multirow[t]{5}{*}{ known this hypermarket } & Between $1-2$ years & 84 & $20.10 \%$ \\
\hline & Between $2-3$ years & 106 & $25.40 \%$ \\
\hline & Between 3-4 years & 67 & $16.10 \%$ \\
\hline & Between $4-5$ years & 41 & $9.80 \%$ \\
\hline & Above 5 years & 87 & $20.90 \%$ \\
\hline How do you know this & Friends & 116 & $27.80 \%$ \\
\hline \multirow[t]{5}{*}{ hypermarket } & Printed advertisement & 58 & $13.90 \%$ \\
\hline & Internet & 54 & $12.90 \%$ \\
\hline & Advertisement & 57 & $13.70 \%$ \\
\hline & Word mouth to mouth & 92 & $22.10 \%$ \\
\hline & Others & 40 & $9.60 \%$ \\
\hline \multicolumn{2}{|c|}{ How often do you shop inEvery day } & 15 & $3.60 \%$ \\
\hline \multirow[t]{5}{*}{ hypermarket } & Once a week & 80 & $19.20 \%$ \\
\hline & 2-3 times a week & 51 & $12.20 \%$ \\
\hline & Once a month & 155 & $37.20 \%$ \\
\hline & 2-3 times a month & 66 & $15,80 \%$ \\
\hline & Others & 50 & $12.00 \%$ \\
\hline \multirow{3}{*}{$\begin{array}{l}\text { Whom do you often go } \\
\text { with }\end{array}$} & Friends & 153 & $36.70 \%$ \\
\hline & Family & 234 & $56.10 \%$ \\
\hline & Others & 30 & $7.20 \%$ \\
\hline \multicolumn{2}{|c|}{ On average how much do Below than RM100 } & 147 & $35.40 \%$ \\
\hline \multirow[t]{4}{*}{ you spend } & RM101-RM200 & 143 & $34.30 \%$ \\
\hline & RM201-RM300 & 91 & $21.80 \%$ \\
\hline & RM301-RM400 & 25 & $6.00 \%$ \\
\hline & RM401 and above & 11 & $2.60 \%$ \\
\hline \multirow[t]{3}{*}{$\begin{array}{l}\text { Where do you currently } \\
\text { reside }\end{array}$} & $\begin{array}{l}\text { Less than } 10 \mathrm{~km} \text { from } \\
\text { the hypermarket }\end{array}$ & 169 & $40.50 \%$ \\
\hline & $\begin{array}{l}\text { Between } 11-20 \mathrm{~km} \\
\text { from the hypermarket }\end{array}$ & 248 & $59.50 \%$ \\
\hline & $\begin{array}{l}\text { More than } 20 \mathrm{~km} \text { from } \\
\text { the hypermarket }\end{array}$ & 0 & \\
\hline
\end{tabular}

According to Table 3 , the majority of respondents have known the hypermarket for about 2-3 years and have heard about it from their colleagues. Following that, 155 of the 417 respondents in this study said they went to the hypermarket once a month. Furthermore, 234 respondents said they go to the hypermarket with their families, accompanied by colleagues. Since the majority of respondents are students with limited purchasing power, the average amount spent on 
hypermarket is less than RM100. Finally, 169 respondents live less than 10 kilometres from the hypermarket, while 248 others live between 11 and 20 kilometres.

\section{Pearson Correlation}

Table 4

Pearson Correlation Scores between Independent Variables and Dependent Variable.

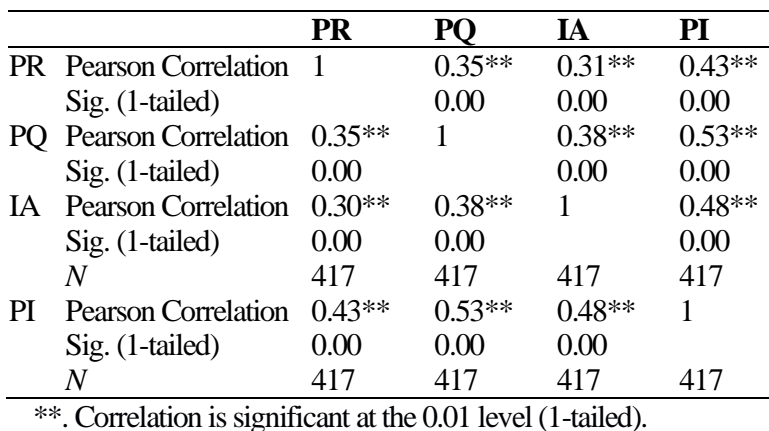

The Pearson Correlation Coefficient is used to assess the strength of the linear relationship between the study's independent and dependent variables. Table 4 indicates the correlation coefficient, which is 0.43 between the price and purchase intention variables. which reflect a direct positive (moderate/medium) relationship. While, the product quality and purchase intention variables have a strong and positive relationship with correlation coefficient of 0.53 . Lastly, interior atmosphere and purchase intention have a close interaction and have a positive correlation since the correlation coefficient of 0.48 and reflect a favorable and moderate relationship. Thus, purchase intention has a direct relationship with the independent variables of price, product quality, and interior atmosphere. It can be concluded that as the level of independent variables rises, so does the level of the dependent variable.

\section{Multiple Regression Analysis}

Table 5

Model Summary

\begin{tabular}{cccc}
\hline Model & $\boldsymbol{R}$ & $\boldsymbol{R}$ Square & Adjusted $\boldsymbol{R}$ Square \\
\hline 1 & $0.64^{\mathrm{a}}$ & 0.41 & 0.41 \\
\hline
\end{tabular}

Based on Table 5 presented model summary in this study. $R$ square value in this study is 0.41 and it is indicated that 41 percent of purchase intention can be explained price, product quality, and interior atmosphere.

Based on Table 6 presented ANNOVA in this study. The significant number showed 0.00 which less than 0.05 which indicated that at least one of the independent variables is significant towards purchase intention.
Table 6

ANNOVA

\begin{tabular}{rcrccc}
\hline \multicolumn{1}{c}{ Model } & $\begin{array}{c}\text { Sum of } \\
\text { Squares }\end{array}$ & $\boldsymbol{d} \boldsymbol{f}$ & $\begin{array}{c}\text { Mean } \\
\text { Square }\end{array}$ & $\boldsymbol{F}$ & Sig. \\
\hline Regression & 24.32 & 3 & 8.11 & 96.61 & $0.00^{\mathrm{b}}$ \\
Residual & 34.67 & 413 & 0.08 & & \\
Total & 58.98 & 416 & & & \\
\hline
\end{tabular}

a. Dependent Variable: Purhcase Intention

b. Predictors: (Constant), Interior atomopshere, Price, Product Qaulity

Table 7

Coeffficients

\begin{tabular}{lcccr}
\hline \multirow{2}{*}{ Model } & \multicolumn{2}{c}{$\begin{array}{c}c \\
\text { Coefficients }\end{array}$} & \multirow{2}{*}{ Sig. } & \\
\cline { 2 - 3 } & $\boldsymbol{B}$ & $\begin{array}{c}\text { Std. } \\
\text { Error }\end{array}$ & & \\
\hline (Constant) & 0.60 & 0.16 & 0.00 & \\
PR & 0.23 & 0.04 & 0.00 & Accepted \\
PQ & 0.34 & 0.04 & 0.00 & Accepted \\
IA & 0.25 & 0.04 & 0.00 & Accepted \\
\hline Noted: PR: Price; PQ: Porduct Quality; IA: Interiror Atmopshere
\end{tabular}

Based on Table 6 presented coefficients result in this study. Three independent variables in this study consists 0.00 on $p$-value and it less than 0.05 which indicated that three variebales in this study are significant towards purchase intention. Therefore, below is the model formula in this study: $\mathrm{PI}=0.60+0.23$ (PR)+ 0.34 (PQ)+ 0.25 (IA).

The formula can be interpreting as when increasing 1 percent of price which indicated 23 percent on purchase intention while remaining product quality and interior atmosphere. Futhermore, when increasing 1 percent of product quality which result 34 percent on purchase intention whiel remaining price and interior atmosphere. Lastly, when increasing 1 percent of interior atmposhere which indicated 25 percent on prucase intention remaining the factor of price and product quality. In summary, product quality defined as the most influential factors in this study.

\section{Discussion}

The finding revealed that three hypotheses are backed by p-values less than 0.05 . Price, product quality, and interior atmosphere are the dimensions that are linked to these endorsed hypotheses. The dependent variable is found to have the greatest causal effect on the three independent variables, with 'Product Quality' having the greatest causal impact. There are no independent variables that are insignificant since their $p$-value is below than 0.05 . As a result, it should be noted that price, product quality, and interior ambiance all have a major impact on consumer purchasing intention. Since the $p$-value is less than 0 and the $r$ is 0.43 , which indicates a mild association with consumer 
purchasing intent, hypothesis 1 is endorsed. This study's findings are consistent with Calvo-Porral and Lévy-Mangin (2017), who found that price has an important and positive impact on consumer purchasing intention. Any hypermarket that can offer a cheaper price than other stores will entice customers to buy the product. This finding backs up previous research by Lien et al. (2015), which found that lower-price promotions significantly increase consumers' perceived shopping value and purchasing intention.

According to this study's findings, product quality and consumer purchasing intention have a $p$-value of less than 0 and $r$-value of 0.53 indicating a good association with the dependent variable. Besides, the product quality justifies as the most influenctial factors in this study. This study's findings are backed up by Erida and Rangkuti (2017), who discovered that product quality has a direct impact on customer purchasing intentions. Customers would not shop at a hypermarket if they are not confident in the product's consistency. This is backed by a previous study by Tudor and Zheng (2014), who discovered that goods of higher quality than comparable products from other brands increased consumers' purchasing intentions.

The $p$-value is less than 0.05 , and the $r$ is 0.48 , indicating that interior atmospheric has an important and optimistic impact on consumer purchasing intention. This study's findings are backed up by previous research by Ishar Ali, Mubarak, and Shameem (2017), Roschk, Loureiro, and Breitsohl (2017), who found that interior atmospheric is positively associated with consumer purchase intention. Furthermore, in order for the interior atmosphere of the hypermarket to draw consumers with the intent to buy, ensure that the lighting is appropriate and capable of making the product appealing to the consumer. Besides, Horská and Berčík (2014) found that lighting is an effective marketing tool that can positively affect and attract customers, resulting in increased sales, and that lighting is an important marketing tool that can stimulate customer purchases.

\section{Conclusions and Implications}

All of the variables examined in this research, such as price, product quality, and interior atmosphere, indicate a positive relationship with customers' buying intentions. A small improvement in any of these variables may have an effect on the customers' buying decisions. The study's goal was to identify the most influential factors in customers' purchasing intentions in the Kota Bharu, Kelantan area. In the study, three factors were discovered. In addition, the study tested three hypotheses that were reported at the beginning. According to the findings, product quality is the most important reason why consumers choose those hypermarkets, followed by interior atmosphere and price. Since the $p$-value was less than 0.05 , all of the hypotheses that were evaluated were acknowledged. As a result, all theories are agreed and backed up. When conducting the survey, the researchers encountered several difficulties. In order to collect precise data, researchers must make it easier for customers to complete the questionnaire. Customers were running to their houses, so time constraints were a major hindrance. The researchers have had difficulty attracting customers' interest. Some of the respondents were hesitant to reply. Besides, obtaining approval from the hypermarket's higher authorities to perform the survey proved difficult. Only three variables have been investigated in this study. In order to obtain more reliable results, it is proposed that future studies incorporate new variables. Finally, the results of this study revealed important information about the variables that influence customers' buying intentions. Researchers also hope that the results of this study will be used to develop the hypermarket industry, as well as other industries.

Below showed the recommendation for future studies: If this research is replicated in the future, it will be best to increase the overall sample size. It is suggested that new research be conducted using qualitative and other empirical methods in order to uncover more diverse and comprehensive findings and to produce results that are necessary to question existing best practises. Future researchers should carefully build questionnaires in order to prevent biased questionnaires and collect useful data. Other aspects of equity, such as "social impact," "external atmospheric conditions," and so on. Since each respondent can have different expectations and factors that affect their purchasing intention against hypermarkets, the statistical relevance of the analysis and the reliability of the findings may be increased.

\section{References}

Ahmed, R. R., Zamir, M., Yazdani, S., \& Mehmood, S. (2016). Factors impacting the buying behavior of housewives towards hypermarkets in Karachi. Journal of Marketing and Consumer Research, 19, 6-12.

Alhabshi, S. M. (2014). Malaysia retail policies and procedures balancing needs and demands. Research Journal of Social Science and Management, 3(10), 95-111.

Asshidin, N. H. N., Abidin, N., \& Borhan, H. B. (2016). Consumer attitude and uniqueness towards international products. Procedia Economics and 
Finance, 35, 632-638. http://dx.doi. org/10.1016/ S2212-5671(16)00077-0.

Bitner, M. J. (1992). Servicescapes: The impact of physical surroundings on customers and employees. Journal of Rarketing, 56(2), 57-71. https://doi.org/10.1177\%2F002224299205600205

Calvo-Porral, C., \& Lévy-Mangin, J. P. (2017). Store brands' purchase intention: Examining the role of perceived quality. European Research on Management and Business Economics, 23(2), 90-95. http://dx.doi.org/10.1016/j.iedeen.201 6.10.001

Cheng, J. X. (2015). Investigation on customer based brand-equity in hypermarket: A case study in Ipoh. Thesis. University of Tunku Abdul Rahman (Faculty of Businesss and Finance), Malaysia.

Derbaix C. (1987). Le comportement de l'acheteur: voies d'études pour les années à venir. Recherche et Applications en Marketing, 2(2), 81-92. https://doi.org/10.1177\%2F076737018700200204

Erida, E., \& Rangkuti, A. S. (2017). The effect of brand image, product knowledge and product quality on purchase intention of notebook with discount price as moderating variable. Journal of Business Studies and Management Review, 1(1), 26-32. https://doi.org/10.22437/jb.v1i1. 3919

Gilmore, H. L. (1974). Product conformance cost. Quality progress, 7(5), 16-19.

Hair, J. F., Sarstedt, M., Ringle, C. M., \& Mena, J. A. (2012). An assessment of the use of partial least squares structural equation modeling in marketing research. Journal of the Academy of Marketing Science, 40(3), 414-433. http://dx.doi.org/ 10.1007/s11747-011-0261-6

Han, H., \& Hyun, S. S. (2015). Customer retention in the medical tourism industry: Impact of quality, satisfaction, trust, and price reasonableness. Tourism Management, 46, 20-29. https://doi. org/10.1016/j.tourman.2014.06.003

Hassan, H., Rahman, M. S., \& Sade, A. B. (2019). Why do hypermarkets extend their brands to brands to a growing number of products? International Journal Business Excellence, 17 (3), 290-305. http://dx.doi.org/10.1504/IJBE X.2019. 097956

Herrmann, A., Xia, L., Monroe, K. B., \& Huber, F. (2007). The influence of price fairness on customer satisfaction: An empirical test in the context of automobile purchases. Journal of Product \& Brand Management, 16, 49-58.

Horská, E., \& Berčík, J. (2014). The influence of light on consumer behavior at the food market. Journal of Food Products Marketing, 20(4), 429-440. https://doi.org/10.1080/10454446.2013 .8 38531
Hosein, N. Z. (2012). Measuring the purchase intention of visitors to the auto show. Journal of Management \& Marketing Research, 10, 1-17.

Hussain, R., \& Ali, M. (2015). Effect of store atmosphere on consumer purchase intention. International Journal of Marketing Studies, 7(2), 35-43. http://dx.doi.org/10.5539/ijms.v7n2p3 5

International Markets Bureau. (2012). Market analysis report: Modern grocery retailing in major ASEAN markets (Indonesia, Thailand, Malaysia, Singapore and the Philippines). Ontario.

Ishar Ali, M. S., Mubarak, K. M., \& Shameem, A. (2017). Interior Atmosphere: Does it really have an impact on consumer purchasing behavior at self-serving convenience stores? Journal of Marketing and Consumer Research, 31, 28 -34.

Issaac, S., \& Michael, W. B. (1995). Handbook in research and evalution: For education and the behavioral sciences. San Diego, CA: Educational and Industrial Testing Services.

Jaliawala, M. M., \& Rahman, M. (2014) Channel switching behavior from traditional grocery stores to branded grocery chains in Karachi. Journal of Independent Studies and Research, 12(2), 1-16. http://dx.doi.org/10.31384/jisrms se/2014.12.2.1

Johnson, B., \& Christensen, L. (2017). Educational research: Quanitative, qualitative, and mixed approaches. $6^{\text {th }}$ Edition. California, USA: Sage Publications.

Kaura, V., Durga Prasad, C. S., \& Sharma, S. (2015). Service quality, service convenience, price and fairness, customer loyalty, and the mediating role of customer satisfaction. International Journal of Bank Marketing, 33(4), 404-422. https://doi.org/ 10.1108/IJBM-04-2014-0 048

Kotler, P. (1973). Atmospherics as a marketing tool. Journal of Retailing, 49(4), 48-64.

Krejcie, R. V., \& Morgan, D. W. (1970). Determining sample size for research activities. Educational and Psychological Measurement, 30 (3), 607610. https://doi.org/10.1177\%2F001 31644700 3000308

Krisnakumar, V. A. P., Sulaiman, Z., Chin, T. A., Masod, A., Zakuan, N., \& Choon, T. L. (2018). Consumer proneness towards in-store promotion in foreign-based hypermarket vs local-based hypermarket. AIP Conference Proceedings 2044, 020011. https://doi.org/10. 1063/1.5080064

Lee, S. Y., Looi, N. Y., \& Woo, C. Y. (2018). Factors that influence consumers' acceptance towards self-checkout system (SCS) in hypermarket Malaysia. Doctoral dissertation. Universiti Tunku Abdul Rahman, Malaysia. 
Lien, C. H., Wen, M. J., Huang, L. C., \& Wu, K. L. (2015). Online hotel booking: The effects of brand image, price, trust and value on purchase intentions. Asia Pacific Management Review, 20(4), 210-218. https://doi.org/10.1016/j.apmrv. 2015.03.005

Lim, Y. J., Osman, A., Salahuddin, S. N., Romle, A. R., \& Abdullah, S. (2016). Factors influencing online shopping behavior: the mediating role of purchase intention. Procedia Economics and Finance, 35, 401-410. https://doi.org/10.1016/ S2212-5 671(16)00050-2

Mirabi, V., Akbariyeh, H., \& Tahmasebifard, H. (2015). A study of factors affecting on customers purchases intention (Case study: The agencies of Bono brand tile in Tehran). Journal of Multidisciplinary Engineering Science and Technology (JMEST), 2(1), 267-273.

Shamsudin, M. N., \& Selamat, J. (2005). Changing retail food sector in Malaysia. Presented at the PECC Pacific Food System Outlook 2005-06 Annual Meeting, Kun Ming, China 11-13 May 2005.

Nguyen, L. T., Jamal, A., O’Brien, J., \& Nawaz, I. Y. (2017). The effect of click \& collect service in the context of retail atmospherics on consumer buying behavior in terms of repurchase intention: An empirical study of Tesco UK. Presented at $4^{\text {th }}$ International Conference on Innovation in Economics and Business 2017.

Pandey, R. (2015). Key factors in hypermarket business that effect on customer's repurchase. Thesis. Bankok University, Thailand.

Rana, S. M. S., Osman, A., \& Othman, Y. H. (2015). Factors affecting purchase intention of customers to shop at hypermarkets. Mediterranean Journal of Social Sciences, 6(3), 429-434. http://dx.doi. org/10.5901/mjss.2015.v6n3p42 9

Razak, I., Nirwanto, N., \& Triatmanto, B. (2016). The impact of product quality and price on customer satisfaction with the mediator of customer value. Journal of Marketing and Consumer Research, 30(1), 59-68.

Roschk, H., Loureiro, S. M. C., \& Breitsohl, J. (2017). Calibrating 30 years of experimental research: A meta-analysis of the atmospheric effects of music, scent, and color. Journal of Retailing, 93(2), 228-240. https://doi.org/10.1016/j.jretai. 2016.10.001

Tudor, A. G., \& Zheng, C. (2014). Product knowledge, product quality and country-of-origin effects on purchase intention of personal computers: A survey of Aalesund University College Students. Master's Thesis. Institutt for internasjonal forretningsdrift.

Walintukan, C., Tumbuan, W. J. A., \& Tulung, J. E. (2018). The effect of product quality, sales promotion and social influence on customers purchase intention in bellagio shoes store in Manado. Jurnal EMBA: Jurnal Riset Ekonomi, Manajemen, Bisnis dan Akuntansi, 6(4), 35333542. https://doi.org/10.35794/emba.v 6i4.21657

Wang, Y. H., \& Chen, L. Y. (2016). An empirical study of the effect of perceived price on purchase intention evidence from low-cost carriers. International Journal of Business and Social Science, 7(4), 97-107.

Younus, S., Rasheed, F., \& Zia, A. (2015). Identifying the factors affecting customers purchase intention. Global Journal of Management and Business Research: A Administration and Management, 15 (2-1), 9-13. 